\title{
Why we need an allocative (and resourceful) welfare state ${ }^{1}$
}

\author{
Por que precisamos de um estado \\ de bem-estar social alocativo
}

CELIA LESSA KERSTENETZKY*

\begin{abstract}
RESUMO: Neste ensaio, proponho uma agenda para o estado de bem-estar do século 21 que enfatiza seu papel como mecanismo alocativo. Como os problemas sociais e ambientais estão fugindo do controle, o tempo da mera compensação passou: urge um mecanismo capaz de influenciar diretamente os sistemas de produção e os padrões de consumo na reconfiguração da socioeconomia. Isso se traduz parcialmente em mudança estrutural em direção aos serviços sociais públicos conduzida pelo estado de bem-estar. Entre as vantagens dessa mudança, além de resultados socialmente mais equilibrados, estão empregos de qualidade e o atendimento a necessidades sociais de forma ecologicamente amigável. A função alocativa que confere ao estado de bem-estar um papel constitutivo na formação da socioeconomia complementa sua função clássica de compensador de problemas. O estado de bem-estar social alocativo deve estar preparado para limitar o domínio da alocação de mercado.

PALAVRAS-CHAVE: estado de bem-estar social; alocação de recursos; serviços sociais públicos; sustentabilidade ambiental.
\end{abstract}

ABSTRACT: In this essay, I propose an agenda for the welfare state of the $21^{\text {st }}$ century that emphasizes its role as a mechanism of resource allocation. Since social and environmental problems are getting out of hand, the time for mere compensation is over: we need a mechanism for directly influencing systems of production and patterns of consumption in the direction of addressing those problems. This partially translates into a decisive sectoral shift towards public social services led by the welfare state. Among the advantages of this move, in addition to more socially balanced outcomes, are quality jobs and fulfillment of social needs in an environment-friendly way. The allocative task which gives the welfare state

\footnotetext{
${ }^{1}$ I thank Jaques Kerstenetzky, Antonio Kerstenetzky, André Albuquerque Sant'Anna, Fábio Waltenberg, Leonardo Burlamaqui, Márcio Alvarenga Junior, and participants to the CEDE Workshop on the allocative welfare state for helpful comments on an earlier version of this article. Remaining errors or inaccuracies are of my sole responsibility. I also warmly thank Márcio Alvarenga Junior for generously computing and providing me with data on environmental backward linkage of social services in Brazil. * Professora at Instituto de Economia da Universidade Federal do Rio de Janeiro - UFRJ, Rio de Janeiro/RJ, Brasil. E-mail: celiakersten@gmail.com; Orcid https://orcid.org/0000-0002-5747-2485. Submitted: 23/April/2021; Approved: 6/May/2021.
} 
a constitutive role in shaping the socioeconomy complements its classic function as problem fixer. The allocative welfare state must be prepared to limit the domain of market allocation. KEYWORDS: welfare state; allocation; public social services; sustainability JEL code: I38, J08, P16.

\section{INTRODUCTION}

When it comes to naming public social provision, there seems to be a preference for terms such as 'social protection' or 'social safety nets' over 'welfare state'. Social protection is prevalent in Brazilian debates, while social safety nets is common language in the ambiance of international organizations. This option is unfortunate, though. First, because it conveys a defensive meaning of public social provision. Second, because education, which does not sit comfortably with the protection semantics but alone can reach a quarter of total social spending, is alienated. The upshot is a deflation of the multifunctional potential of the welfare state and the depoliticization of it. In this essay, I advocate instead the use of the term welfare state.

To begin with, a crucial feature of the welfare state category is that it refers the many occurrences of public social provision including education to a systemic logic, as a point of reference: policies should have complementarities, sense tradeoffs, and provoke search for coherence to attain agreed purposes. Moreover, by utilizing the term welfare state we mean to be talking about a political category - a form of state which decanted after myriad events, such as conflicts, accommodation, inertia, institution building, and institutional disruption, irrigated by systems of beliefs and ideologies.

Relatedly, insisting on the political is further justified by practical reasons as well. Even before we start devising tactics, including the design of supportive coalitions for a public social provision agenda, we need an agenda in the first place. And this cannot be settled via technocratic fiat. Of all questions, how transformative should this agenda be and, of course, towards which direction are strongly contested ones.

In this essay, I claim a specific sense for the welfare state as a transformative artifact. This includes an upfront commitment to reducing economic inequalities, including attention to the entire distribution of income and wealth, but also, and more broadly, a commitment to strengthen societies in the face of environmental and social challenges. ${ }^{2}$ To grasp the full range of the welfare state potential, I review its twofold central role as follows.

I initially present an evaluation of the crucial role of the welfare state in devastating crises such as the financial crisis starting in 2007-2008 and the health crisis

\footnotetext{
2 This proposal largely coincides with the Green New Deal (GND), partially advanced by the Biden government in the US, in terms of general aims. In more specific terms, this proposal, while referring exclusively to social policy, is thus both more modest in scope and more systematic when it comes to social policy proper than the GND.
} 
starting in 2020. This evaluation, while stressing the immunizing character of the myriad institutions, agencies, and programs that are integral to the welfare state, in that they softened disruptive forces unleashed by crises, unearths the problemsolver quality of the welfare state. And so also that, while essential, the welfare state has been an insufficient response to the challenges it faced.

Following that initial assessment, I present a tentative agenda for the kind of welfare state which is currently needed. This, I claim, is one which, rivalling with market mechanisms, takes up an allocative function. To be clear, the welfare state literature emphasizes the distributive function of the welfare state, its ability to change the income or wealth distribution. What I am talking about instead is the welfare state's ability of exerting a direct influence on patterns of production and associated patterns of consumption. ${ }^{3}$ Moreover, what I suggest here is: (1) that the welfare state has always (although mostly inadvertently) performed such allocative function, but (2) while this function has gone largely unremarked, it now needs to be brought to the fore, advocated for, and duly expanded. This function is related, I claim, to the potential of the welfare state to lead a veritable 'structural change within the structural change', i.e., fundamentally redirect economic trends, and thus address the pressing economic-social-environmental challenges before us.

\section{THE WELFARE STATE AS A PROBLEM-SOLVER}

The crisis of 2007-2008, the so-called Great Recession, and the coronavirus health crisis starting in 2020 have both corroborated the long-recognized need for a welfare state. In both events, the welfare state through its various policies, programs, and agencies was and has been able to critically soften the major social and economic impacts of the crises.

Let us first consider the Great Recession. Our own investigation of the evolution of social spending as well as strategic actions undertaken by different welfare states in different countries and country-clusters disclosed that the welfare states of OECD countries increased 3 percentage points of GDP between 2007 and 2014 (Kerstenetzky $\&$ Guedes 2020). This amounted to an increase that surpassed the expansion that took place from 1980 to 2006, on that measure. Other measures of social spending, such as real social expenditure, real per head and real per dependent social spending roughly confirmed the increase observed in the percentage-of-the-GDP measure (see Table 1). All programs that are computed by the OECD database displayed expansion, but, of course, those that increased most were automatic stabilizers such

\footnotetext{
3 Accordingly, Musgrave \& Musgrave (1989) referred to the allocation, distribution and stabilization functions of the state, when discussing the public budget. Updating their framework to comprise the welfare state, a specific state form, allows me to disentangle those functions as they are performed by it, i.e., as provider of social goods, modifier of the distribution of income and wealth, and driver of employment. In particular, the use of the terms 'allocation' and 'allocative' in this paper does not refer to allocative efficiency in the neoclassical microeconomic sense.
} 
as unemployment insurance and social assistance. Still, while all social needs increased following the crisis, the welfare state inertially responded to all of them. In the aftermath of the crisis, structural drivers such as ageing populations took the front seat in leading the continued expansion from 2011 on. Stability of this benign Leviathan is a safe conclusion. Without it, poverty and inequality would have increased immensely, reaching about the double and the triple, respectively, of the observed rates in 2013 (Kerstenetzky and Guedes 2020).

Below the radar of averages, some strategic moves were detected. The changes, which were led by the Nordic countries, disclosed a new logic of the welfare state. This new logic which was already detectable back in the 1990s amounts to claiming a preventative role for the welfare state, as supportive to gendered employment and productivity. It has translated, in policy terms, into extensive spending on education, especially lifelong learning, including early childhood education and care (ECEC), social care for the elderly, and active labor market policies (programs of training, retraining, and matching) coupled with social security. Outside the Nordic cluster other countries have engaged in the experiment, including Germany, the Netherlands, Austria and, more recently, South Korea, which displayed the greatest proportional expansion of social spending in the aftermath of the financial crisis.

Incidentally, the Nordic social model, also known as the social democratic model, had already coped with problems of political sustainability by moving towards universalism back in the 1930s (everyone benefits, though the richer pay absolutely and proportionally more) before it dealt with problems of economic sustainability by engaging in social investment in the post-war era. All in all, this meant extending the function of social policy beyond that of social glue (implied in universalism) to that of productive factor (implied by its supporting employment and productivity).

The partial reinvention of the welfare state as a preventative 'social investment' problem-solver, though crucial, amounted to an only limited enhancement of society's resilience in the face of devastating crises. It is not only that the kind of solution advanced by the best social model did not spread worldwide, even when considering the context of the advanced economies solely - although in the cases where it did spread, it may have given the countries that followed their lead a comparative advantage in dealing with social problems. The more disturbing fact is that the problems themselves were becoming increasingly more difficult to cope with in the first place. Two areas that had previously seen market-friendly reforms continued to pose critical challenges to welfare state's capacity to deliver some social balance. The reforms were those of labor markets and tax systems; the deregulation and regressive moves that ensued, which were responded almost everywhere with increased redistributive effort, still resulted in more inequality and poverty overtime (Kerstenetzky and Guedes 2020).

When the Covid-19 pandemic struck, that was pretty much the situation on the ground. The health crisis and then the economic and social crises would certainly have been way more devastating than they ended up being had it not been for the welfare state. As we speak, advanced countries, as well as emerging economies, 
expanded public spending beyond imagination (see IMF 2021). And it was the welfare function within the state that expanded most: public health systems, employment support, wage subsidies, unemployment insurance, social assistance, means for remote education. Denmark with its usual 40 percent of GDP dedicated to public social provision, which increased sizably as a response to the pandemic, was able to provide a more balanced protection to its citizens than countries such as the US which, with a similar level of welfare spending but only $60 \%$ public, was more deeply hit in terms of leaving swathes of already vulnerable social groups unprotected (see Dasgupta et al. 2020). Again, within Europe, the UK which had seen an important residualization of its welfare state under the Conservative-led coalition after 2010 faced a devastating social crisis including an outstanding record of excess deaths after the pandemic, while, again, Denmark with a universalist welfare state proved better prepared, including with no excess deaths (see Pickett and Wilkinson 2020; Elgar et al. 2020; Furceri et al. 2021). And yet, even countries that already had robust welfare systems in place and were undeniably better positioned to face the negative fallout of the health crisis are likely to emerge from the triple crisis more unequal on various counts. In fact, several of them foreseeing the bleak future are already designing large investment programs for the aftermath of the pandemic.

\section{PASSIVE AND PREVENTATIVE WELFARE STATE}

Passive and even preventative welfare states, for all their merits, still represent an incomplete response to the big challenges of the day. To see this, let me first briefly review the evolution of the post-war welfare state in relation to the dangers they confronted.

Post-war welfare states responded, each according to their institutional makeup, to the social risks of the time, i.e., those related to industrialization and urbanization processes, and post-war national reconstruction mobilization. (Competition with a distinctive socialist alternative cannot be discarded as additional motivation. ${ }^{4}$ ) The response, in addition to the setting up or expansion of public services, amounted to large-scale organization of collective insurances and (more or less) universal social security schemes to cover for illnesses, work accidents, old age, incapacity, unemployment, and family formation. A complex institutional architecture which involved different social groups including trade unions, employers' associations, governments at all levels, political parties and parliamentary coalitions in each case came up with a template resulting, generally speaking, in the so-called 'growth consensus' of the 'glorious thirties'.

\footnotetext{
${ }^{4}$ In fact, Sant'Anna and Weller (2020) provide robust evidence of the association between the spread of communist revolutions and lower levels of income inequality in western capitalist countries during the Cold War.
} 
As from the 1980s, despite much non-specialized talk about the end of the welfare state, welfare states kept growing, less in the 1980s, more so in the 1990s and the first fifteen years into the $21^{\text {st }}$ century, including in the period of the infamous Great Recession and its aftermath, as discussed above.

The new 'inglorious forties' posed new challenges to welfare states under the form of the new social risks (NSR) of post-industrial societies: structural change towards a service economy, deindustrialization, the IT and automation revolution, globalization with its opening to capital and skilled-labor mobility, long-term unemployment of the lower skilled (usually the youth), population ageing, changes in family composition combined with increased female economic participation. All of which melted down the basis upon which the post-war welfare state had been built, i.e., plain, stable, and quite egalitarian gainful industrial employment of mostly male (generally also unionized) workers, who were also the breadwinners of traditional families, had life expectancies in tune with their pension contributions, and counted on the care services provided by their non-gainfully working wives within their households. The new times would face a dualized labor market with increasing in-work poverty, long-term unemployment, a pending care crisis, and the threat of unsustainable pension funds.

In the face of the new risks, every welfare state on the face of the earth underwent reforms. And while in the 1980s reforms were quite timid or 'parametric', e.g., stressing compressed entitlements and enhanced contributions, they became bolder or 'paradigmatic' in the 1990s and 2000s. The general direction was activation, i.e., recalibration of traditional insurances and security to help support employment, premised on the idea of fixing social policy incentives or, even more radically, reframing social policies as a productive factor. This is a wide-ranging subject; in each welfare regime it gained a different meaning. But I want to focus on what might be considered the best path towards activation, the social democratic version of social investment.

In distinction to other cost-compressing activation variants, such as those undertaken in the US and the UK but also, to some extent, in Germany with the Hartz (labor market) reforms, social democratic activation featured a combination of social security and productive social policy that emphasized higher revenues over lower costs. The expansion of revenues was premised on social policies that boosted aggregate productivity, but also occupational and social mobility, without compromising the well-being of the individuals. This is what I call the preventative mode of the welfare state - preparing citizens to better face the NSR, without leaving them at their own peril afterwards.

As an illustration, women-friendly policies such as social care and ECEC have proved handy to increase low fertility rates, while reducing the pressure of ageing over the pension system, by softening the tensions faced by women of reconciling family and work as they are now freer to engage in the labor market including with full-time and career jobs. At the same time, children have ample access to early education and care which has proved to enhance their life chances including in well-paying jobs. Among the results, in addition to lower inequality and poverty levels and higher social mobility, are increased revenues for the welfare state keep doing what it has been doing. 
Again, for all their merits, and I will come back to these more ahead, even this best model is challenged by what might be called newer social risks. I have in mind the challenges posed by digitalization and artificial intelligence, the more likely occurrence of pandemics, and the frightening climate crisis - not to mention the takeoff of the very rich, the flirtation with austerity and the identitarian takeover of democracies, the latter two, arguably more of a challenge to other countries in Europe and elsewhere than to the Nordic. Serious stuff ahead: jobs, health, social fabric, political communities, even the planet, all at risk. The socioeconomic system seems to be failing us in quite a deep and irremediable sense. Is even the best preventative approach such as the Nordic doubling the bets on a system that has brought us to the verge of an abyss?

\section{CONSTITUTIVE WELFARE STATE: 'STRUCTURAL CHANGE WITHIN THE STRUCTURAL CHANGE’}

While there may be visions of post-capitalist societies and thus of leaps over the abyss, I want to try my hand on a different picture. This is to explore the potentiality of a human artifact that already exists in engaging in a constitutive way with the socio-economy, i.e., the welfare state. The idea here is that we need a service welfare state to harness the service economy, which is at the forefront of our contemporary malaise, and boost a service socio-economy.

The heart of the matter seems to me to be the way our socioeconomic systems allocate resources, mainly via the market mechanism and the profit motive. This mechanism has proved to fail minimum standards of social justice and seriously to threaten the objective survival of the human species, as it unabashedly accommodates highly divisive inequalities and daily destructions of the environment that we share with other species. The fiction of market efficiency had as a normative 'last resort' justification the expectation that aggregate benefits would outweigh costs and render compensation at least possible. This expectation has been falsified, and not only for political economy reasons (i.e., the foot-dragging of the 'winners' to pay taxes). The sense of what constitutes either a benefit or a cost has changed and so has the currency in which each of them are to be gauged, often not the same. To illustrate, how can vaccine patent rents possibly compensate for life losses? How can mining profits compensate for the disappearance of the life forms of indigenous peoples? How can oil profits compensate for irreversible and catastrophic global warming? How can astronomic capital gains and economic rents protect against the sadistic whims of fascist autocrats?

The alternative allocative mechanism, mono-technocratic central planning, also had its shot and failed loudly - it repressed innovation; more importantly, it also repressed political and civil freedoms. The same appetite for economic surplus and thus for eating out natural resources as though they were free goods, however collectively distributed, animated the socialist central planning experience Soviet style. 
And the combination of market and central planning Chinese-style seems to combine the worst of two systems: the profit motive and the lack of freedoms. ${ }^{5}$

What has the welfare state to offer here? I think the welfare state should be reinvented as an allocative mechanism well positioned to face the challenges ahead - if not a full replacement of other mechanisms, it however must take over a more protagonist role. It may be argued that the welfare state already performs this role - how can this be otherwise if we see that between 30 to 40 percent of the GDP of advanced economies is devoted to social spending? Emphasis however has been on its distributive role (re-distributive or pre-distributive), after allocation via other means already had taken place - it would simply be a matter of transferring already generated income flows from one side to the other of the socioeconomic system. But the interpretation of it as an allocative mechanism requires a reframing entirely.

More to the point, it requires a resignification of what the welfare state, especially the best social model, already does to some extent. Starting with a clearer sense of what it already does, the idea is to imagine how the welfare state can more actively and self-consciously participate in the configuration of the new socioeconomy, the service socio-economy. This participation in few words means an active design of the production system - and by implication also of the consumption system - towards the generation of activities that cater directly to wellbeing while creating good jobs and being environment-friendly. To be clear, I am not talking about an old-style entrepreneurial state but a state that provides a broad range of social services, i.e., an allocative system controlled by democratic social choices.

Bringing this social service provision into the mainstream of the production system means giving it a veritable force of 'structural change within the structural change'. In other words, following this line of reasoning, the shift of the economic system from manufacture towards services of the last 4 to 5 decades would be compounded by a shift within the service sector from other services to those more directly connected with social needs. True, most advanced economies already display a robust social services sector. And yet, the examination of the advantages of enlarging this participation may be seen from a simple comparison of the relative size of the social services sector in the best social model, the Nordic one, with that of the other advanced economies - this comparison suggests different service regimes and provides an initial reference point for future improvements (see Table 2). This shift is associated with high levels of wellbeing, less inequalities including gender inequities, a large middle class, a relatively light ecological footprint, a sizable number of good jobs, in addition to socially cohesive societies (see Kenworthy 2020; Zimmermann and Graziano 2020).

It should be kept in mind that in our service economies, it is the service sector

\footnotetext{
${ }^{5}$ Although China's success in market-shaping and state-capacity building has been the focus both of much interest and positive assessments, for the observation of which I thank Leonardo Burlamaqui, I still lexicographically abhor the authoritarian and totalitarian means to those ends on normative grounds.
} 
that serves as the engine of job creation. It accounts for up to $80 \%$, in advanced economies, and already over $70 \%$, in emerging economies, of all the jobs that exist. This means bad and, at least potentially, good news. The bad news is that, as the literature documents, jobs in the service sector are polarized, and while both low- and high-end jobs have been increasing, the middle range has been kept hollow. It may however be argued that this predicament is truer of countries like the US than it is of countries like Sweden or Denmark. And the reason is twofold: the sheer sizable weight of the social services and the fact that most of them are publicly provided in the latter countries. In addition, the comprehensive collective bargaining and other labor market institutions typical of those countries contribute to increasing the value of low-end jobs in the service sector. So, the middle range is in those countries occupied by public sector social service (unionized) jobs, which, in addition to being good jobs, fulfill a diversity of social needs, and have a synergetic relation with the (highly productive) productive services subsector, which includes services of information and communication technologies and other knowledge-intensive activities. The latter is evidently explained by the fact that an educational and culturally rich, as well as healthy, workforce is cultivated thanks to the consumption of inputs uniquely produced by social services.

To what extent these jobs, any job for that matter, can be replaced by artificial intelligence is an important question, but it is secondary to an antecedent and more important one regarding the direction and uses of technology. Anthony Atkinson argues that there always is a choice involved and this choice is made not only by private agents aiming at profits but also by stakeholders including governments with more collective purposes (Atkinson 2015). Governments count on myriad legitimate tools (procurement, credit, regulation, investment, taxation) to direct or redirect technological trajectories towards the search of solutions to problems that are singled out by democratic social choices. As noted by both Anthony Atkinson and David Autor (2021), technology might help eliminate undesirable jobs, augment, and complement human labor, in addition to create new jobs in news areas. The so-called 'human-centered artificial intelligence' is an option on the table.

\section{POLICY COMBINATION: AN ILLUSTRATION}

We want jobs, though not the bad ones, i.e., those that are 'natural resources'intensive, low paying, and patently ungratifying. Here the allocative function of the welfare state should take the front seat by leading a sizable expansion of the 'human resources'-intensive public social services sectors, including education, health care, care, public transport, social housing, connectivity, culture, leisure. This means a sizable amount of resources devoted to public consumption, less so for private consumption - and thus less for wellbeing stratification and 'material resources'intensive goods and services. In fact, while services in general, though people-intensive, respond to high levels of total carbon emissions and use of materials when 
intermediary consumption is factored in, ${ }^{6}$ public social services, in addition to also being people-intensive, involve economies of scale related to public instead of individualized final consumption and thus contribute to release pressure on the environment. ${ }^{7}$ In the end, the shift towards public social services would translate into myriad good, unionized jobs, in people-intensive activities, fulfilling social needs and general wellbeing through collective provision.

To the extent that it is not possible to eliminate all bad jobs, the next-best move is to eliminate those jobs that are incompatible with our finite planet and see to it that the ones that were not eliminated, because e.g., technology was not able to help us out, do not keep people stuck in them, and that, while people are engaging in them, the conditions and rewards be socially acceptable. So, direct or redirect technology to help eliminate brown as well as disagreeable private sector jobs through the induction tools at the state's disposal is also part of the allocative agenda of the (eco)welfare state. And those bad jobs that remain should be addressed by interventions such as lifelong learning and active labor market policies - in addition to labor market institutions that boost the bargaining power of workers, such as comprehensive collective agreements and minimum wages. Here the preventative function of the welfare state, in tandem with the passive one, stands out.

More ambitiously, we may also aim at increasing people's freedom to opt out of bad positions and even try new ventures. The first would be helped by minimum income guarantees while the second, by schemes of democratization of capital, such as social inheritances. These initiatives, in addition to the ones mentioned above, will certainly require enhanced as well as progressive taxation including on wealth. This extra revenue which would help put them in operation gives additional significance to the enhanced allocative function of the welfare state as it also addresses the economic, social and political imbalances caused by the takeoff of the extraordinarily rich. This program might be taken over by the welfare state by activating its triplet function: passive, preventative and constitutive.

In sum, this agenda involves a set of initiatives in three main areas: labor, capital and taxation. In addition to new jobs created in social services, extant brown jobs should be eliminated, still others should be turned transitory, while other freedoms are added, such as those permitted by enjoying a social minimum and receiving some capital endowment.

\footnotetext{
${ }^{6}$ See, e.g., Ge and Lei (2014) input-output analysis, for the case of China, and Fourcroy et al. (2015), for the French case.

7 In fact, Márcio Alvarenga Junior in an as yet unpublished work has shown the environmental backward linkage (which includes direct and indirect carbon emissions) of education and health in Brazil in 2018 to be rather low, among the lowest considering all economic sectors.
} 


\section{BRAZIL?}

In this section I briefly refer to results of a detailed study of the Brazilian labor market that reported the evolution from 2002 to 2014 of a number of labor market indicators including employment and unemployment rates, average earnings, earnings inequality, P10 pay, formalization, unionization, incidence of long hours, as well as various workers' characteristics, according to sectors of economic activity, with a focus on the service sector and from a comparative perspective (Kerstenetzky \& Machado 2018).

It turns out that the Brazilian labor market (LM), following the international trend, is increasingly dominated by service sector jobs - in 2014 , over $65 \%$ of all jobs in the economy from $59 \%$ in 2002 . And that, despite all progress in the labor market that occurred in the timeframe of our research (e.g., impressive rates of formalization across the board), it is the less interesting (considering LM indicators and workers' characteristics) subsectors of distributive and personal services which still dominate the service sector employment, responding for over $60 \%$ of the jobs within it. In the period from 2002 to 2014 , this situation was pretty much consolidated, except for a sizable reduction of domestic services and an increase of the so-called productive services as shares of sectoral employment, the latter still with a meagre participation of less than $15 \%$. Alas, the social service subsector saw its share shrunk somewhat, from $26 \%$ to $25 \%$ of sectoral jobs. To recall, this is a missed opportunity for enhancing human capabilities, productivity, social mobility, and innovation.

This predicament sets Brazil in a position of backwardness in relation to developments in OECD countries, but also when considering emerging economies such as China, South Africa, Argentina, and Uruguay. In fact, while social services are prevalent in developed economies (ranging from $34-45 \%$ of the sectoral jobs) and have relatively high participation in the latter economies (ranging from 29-55\%), the sizable share of low-end personal service jobs in Brazil (24\%), where food, lodging and domestic services are included, is distinctive in a comparison with OECD (10\%), emerging economies (15\%), and Latin American and Caribbean countries $(20 \%)$.

And yet, jobs in the social services in Brazil, especially in the public social services, have attractive features from the standpoint of quality employment, equity and wellbeing. These include high levels of formalization, union density, and minimum pay as well as high rates of women, non-whites and youth participation. Also, considering the low level of public employment in Brazil, only $12 \%$ of all the employed when the US rate is $14.5 \%$, the OECD average is $21.3 \%$, and the rates of the more egalitarian Nordic countries may reach as much as $45 \%$, there is an important gap to be explored to reach the threshold fixed by current welfare states. ${ }^{8}$

8 This does not deny the need to make delivery of existing social services more effective than they currently are and that effectiveness and social control should be integral to the agenda of the allocative 
In fact, the investigation of this gap in terms both of expected effects on the quality and quantity of jobs in Brazil and environment-friendly fulfillment of social needs is the subject of an empirical sequel to this short essay. Incidentally, indicators of insufficient public provision of social services in Brazil, and thus of badly unfulfilled social needs, abound. A synthetic measure is provided by the quite low per capita public spending in health and education in purchasing-power parity, which roughly amount to one third and one half of that of OECD countries (see Trebat 2021).

\section{CONCLUDING REMARKS}

In closing, two disclaimers and a further restatement are in order.

First, this is an exercise on the transformative potential of social policy, and so it is mute on other interventions, in other areas of public interest, that are important on their own and even from ecological and distributive viewpoints. No doubt agricultural or energy or transport policies may be more directly impactful than the shifting of sectoral production and jobs generation towards social services when it comes e.g. to limit carbon emissions or ecological footprint. The point here is that sectoral shift if ambitious enough may nonetheless help relieve pressure on natural resources (including averting zoonoses) and energy supply while a universalist welfare state may influence e.g. transport policy in favor of mass public transportation and energy-efficient social housing. Also, social policy can help via a combination of tax-transfer-services smooth environment-friendly adjustments and transitions, e.g., in agriculture, transport and construction, from activities or practices that are detrimental to the environment and thus generate brown jobs toward others with lighter ecological footprints and clean jobs. Think, e.g., of tax-based social security supporting (re)training and relocation of workers. In the end, while this essay does not intend to offer a totalizing view of public intervention, far from it, it nonetheless advocates for a greater ambition of social policy having in mind a wide range of potential outcomes.

A second consideration is that what has been proposed does not deny the coexistence of markets, private property, private consumption, profits, but limits these to what is compatible with an equitable and sustainable socio-economy, having in mind the current inequitable, unsustainable and intrinsically inefficient situation. Benefits are not outweighing costs as we reached a point where these are incommensurate, ruling out compensation. The proposal is for a mode of co-habitation with a protagonist role for the welfare state.

Finally, when we ask which welfare state configuration works best, the Nordic experiment comes to many minds. In the post-war era, universal social security and services, i.e., direct and indirect income guarantees, were the initial focus. But then,

welfare state. The nuts and bolts of the good experiences, both inside the country and abroad, should be the object of foremost interest. 
solidarist active policies supporting employment with the aid of both cash and services started to attract attention especially after the sobering 1980s which marked the end of the growth consensus. What this essay has suggested is a further reappraisal of what the welfare state already does by focusing attention on its hidden allocative function. The interesting question seems to me to be, having in mind the best social model, how much might be gained by deliberately expanding the allocative domain. Expanded public social services, by fulfilling social needs, re-center patterns of production and consumption around what really matters, i.e., ecology-friendly human wellbeing. In the end, this is not an exercise on leaping over the abyss, let alone building up fences, but on reframing. It is seeing the welfare state as constitutive in a fundamental way of an equitable and sustainable service socio-economy.

\section{REFERENCES}

Atkinson, Anthony 2015, Inequality: what can be done? Harvard University Press.

Autor, David 2021, The work of the future: where it will come from? https://www.lse.ac.uk/ Events/2021/05/202105051800/work. Accessed on 5 May 2021.

Dasgupta, Sharoda et al., Association Between Social Vulnerability and a County's Risk for Becoming a COVID-19 Hotspot - United States, June 1-July 25, 2020. Available in https://www.cdc.gov/ $\mathrm{mmwr} / \mathrm{volumes} / 69 / \mathrm{wr} / \mathrm{mm} 6942 \mathrm{a} 3 . \mathrm{htm}$. Accessed on 21 June 2021.

Elgar, Frank J., Anna Stefaniak, and Michael J.A. Wohl, The trouble with trust: Time-series analysis of social capital, income inequality, and COVID-19 deaths in 84 countries, Soc Sci Med. 2020 Oct; 263: 113365. Published online 2020 Sep 16. doi: 10.1016/j.socscimed.2020.113365

Fourcroy, Charlotte, Faïz Gallouj et Fabrice Decellas. La matérialité invisible des services et ses implications énergétiques : une estimation de l'énergie grise par la méthode input-output. Revue d'économie industrielle 149, 1er trimestre 2015. Varia

Furceri, Davide, Prakash Loungani, Jonathan D. Ostry, and Pietro Pizzuto. 2021. The rise in inequality after pandemics: can fiscal support play a mitigating role? Industrial and Corporate Change, 2021, 1-13. doi: 10.1093/icc/dtab031

Ge, Jianping and Yalin Lei, Carbon emissions from the service sector: an input-output application to Beijing, China. Climate Research, V, Vol. 60: 13-24, 2014doi: 10.3354/cr01224

IMF, Fiscal Monitor Database of Country Fiscal Measures in Response to the COVID-19 Pandemic. Available in https://www.imf.org/en/Topics/imf-and-covid19/Fiscal-Policies-Database-in-Response-to-COVID-19. Accessed on 21 June 2021.

Kenworthy, Lane, Social democratic Capitalism, Oxford University Press, 2020.

Kerstenetzky, Celia Lessa, and Graciele Pereira Guedes, "Great Recession, great regression? The welfare state in the twenty-first century", Cambridge Journal of Economics, Volume 45, Issue 1, January 2021, Pages 151-194

Kerstenetzky, Celia Lessa \& Daniele Carusi Machado 2018, Labor Market Developments in Brazil: formalization at last?, in: Werner Baer, Edmund Ammann \& Carlos Alberto Azzoni, The Oxford Handbook of the Brazilian Economy, Oxford University Press.

Musgrave, Richard A. and Peggy B. Musgrave, Public Finance in Theory and Practice ( $5^{\text {th }}$ edition), MacGraw-Hill International Editions, 1989.

Pickett, Kate and Richard Wilkinson 2020, Greater equality: our guide through Covid-19 to sustainable wellbeing. Available in https://socialeurope.eu/greater-equality-our-guide-through-covid-19-to-sustainable-wellbeing; accessed on 21 June 2021.

Sant'Anna, André Albuquerque; Weller, Leonardo, The Threat of Communism during the Cold War: A 
Constraint to Income Inequality? Comparative Politics, Volume 52, Number 3, April 2020, pp. $359-393(35)$

Trebat, Thomas 2020, Growth, Equity, and Labor Markets: Nordic Lessons for Brazil, Unpublished manuscript.

Zimmermann, Katharina and Paolo Graziano, Mapping Different Worlds of Eco Welfare States, Sustainability, 12, 1819; doi:10.3390/su12051819, 2020

Table 1: Public social spending tendency - \%

of GDP and per head** - OECD (2007/2013)

\begin{tabular}{|c|c|c|c|c|c|c|c|}
\hline Branches & 2007 & 2013 & Tendency & Branches & 2007 & 2013 & Tendency \\
\hline $\begin{array}{l}\text { Public Social } \\
\text { Expenditure }(\% \mathrm{GDP})^{1}\end{array}$ & 23.00 & 26.03 & & ALMP (\%GDP) & 0.49 & 0.54 & \\
\hline $\begin{array}{l}\text { Public Social } \\
\text { Expenditure (Per Head)* }\end{array}$ & $6,906.0$ & $8,115.4$ & & ALMP (Per Head) & 170.9 & 196.3 & \\
\hline Old Age (\%GDP) & 6.21 & 7.63 & & $\begin{array}{l}\text { Unemployment } \\
\text { (\%GDP) }\end{array}$ & 0.73 & 0.99 & \\
\hline Old Age (Per Head) & $2,265.2$ & $2,796.6$ & & $\begin{array}{l}\text { Unemployment } \\
\text { (Per Head) }\end{array}$ & 264.4 & 375.0 & \\
\hline Survivors (\%GDP) & 1.04 & 1.08 & & Housing (\%GDP) & 0.43 & 0.44 & \\
\hline Survivors (Per Head) & 337.8 & 335.5 & & $\begin{array}{l}\text { Housing (Per } \\
\text { Head) }\end{array}$ & 115.2 & 137.4 & \\
\hline Incapacity (\% GDP) & 2.08 & 2.21 & & $\begin{array}{l}\text { Other social policy } \\
\text { areas (\%GDP) }\end{array}$ & 0.47 & 0.53 & \\
\hline Incapacity (Per Head) & 805.0 & 869.0 & & $\begin{array}{l}\text { Other social policy } \\
\text { areas (Per Head) }\end{array}$ & 175.0 & 215.9 & \\
\hline Health (\%GDP) & 5.38 & 6.11 & & ECEC (\%GDP) & 0.57 & 0.72 & \\
\hline Health (Per Head) & $2,028.2$ & $2,301.5$ & & ECEC (Per Head) & 200.9 & 273.1 & \\
\hline Family (\%GDP) & 1.94 & 2.17 & & $\begin{array}{l}\text { Education } \\
(\% \text { GDP })^{1}\end{array}$ & 4.22 & 4.33 & \\
\hline Family (Per Head) & 765.7 & 850.7 & & $\begin{array}{l}\text { Education (Per } \\
\text { student) }^{2}\end{array}$ & \multicolumn{3}{|c|}{$20,036.622,947.0$} \\
\hline
\end{tabular}

Source: Kerstenetzky and Guedes (2020).

Note: ${ }^{1}$ The data for the year 2007 concern the year 2008 because for 2007 information on education is not available.

Note: ${ }^{2}$ Education (per student) takes into account public and private spending.

Note: ${ }^{*}$ It does not consider spending on education.

Note: * At constant prices (2010) and constant PPPs (2010) in US dollars. 
Table 2: Employment by service subsectors and country clusters (\%)

\begin{tabular}{|c|c|c|c|c|}
\hline Country & Productive & Distributive & Social & Personal \\
\hline \multicolumn{5}{|l|}{ The Anglo-Saxons } \\
\hline Australia & $19.3 \%$ & $31.9 \%$ & $35.7 \%$ & $13.0 \%$ \\
\hline Ireland & $19.9 \%$ & $31.5 \%$ & $35.4 \%$ & $13.2 \%$ \\
\hline New Zealand & $21.2 \%$ & $33.5 \%$ & $34.3 \%$ & $10.9 \%$ \\
\hline United Kingdom & $21.7 \%$ & $28.7 \%$ & $39.0 \%$ & $10.6 \%$ \\
\hline United States & $23.2 \%$ & $28.3 \%$ & $36.8 \%$ & $11.8 \%$ \\
\hline Mean & $22.7 \%$ & $28.6 \%$ & $37.0 \%$ & $11.7 \%$ \\
\hline \multicolumn{5}{|l|}{ The Nordic } \\
\hline Denmark & $16.6 \%$ & $30.2 \%$ & $44.7 \%$ & $8.5 \%$ \\
\hline Finland & $19.7 \%$ & $30.9 \%$ & $40.2 \%$ & $9.3 \%$ \\
\hline Norway & $17.1 \%$ & $30.1 \%$ & $46.0 \%$ & $6.8 \%$ \\
\hline Sweden & $21.4 \%$ & $27.7 \%$ & $43.2 \%$ & $7.7 \%$ \\
\hline Mean & $19.1 \%$ & $29.3 \%$ & $43.6 \%$ & $8.0 \%$ \\
\hline \multicolumn{5}{|c|}{ Continental Europe } \\
\hline Austria & $19.7 \%$ & $33.7 \%$ & $35.2 \%$ & $11.4 \%$ \\
\hline France & $19.5 \%$ & $28.8 \%$ & $42.8 \%$ & $8.8 \%$ \\
\hline Germany & $20.5 \%$ & $32.3 \%$ & $38.8 \%$ & $8.4 \%$ \\
\hline Netherlands & $22.0 \%$ & $30.6 \%$ & $39.2 \%$ & $8.1 \%$ \\
\hline Switzerland & $25.4 \%$ & $28.7 \%$ & $37.1 \%$ & $8.8 \%$ \\
\hline Mean & $20.6 \%$ & $30.8 \%$ & $39.9 \%$ & $8.7 \%$ \\
\hline \multicolumn{5}{|l|}{ The LAC } \\
\hline Argentina & $13.8 \%$ & $36.2 \%$ & $31.9 \%$ & $18.1 \%$ \\
\hline Costa Rica & $17.9 \%$ & $38.7 \%$ & $23.8 \%$ & $19.5 \%$ \\
\hline Cuba & $5.1 \%$ & $24.9 \%$ & $55.6 \%$ & $14.4 \%$ \\
\hline Mexico & $11.1 \%$ & $45.3 \%$ & $22.5 \%$ & $21.1 \%$ \\
\hline Peru & $10.1 \%$ & $49.1 \%$ & $21.8 \%$ & $18.9 \%$ \\
\hline Uruguay & $13.5 \%$ & $36.7 \%$ & $28.6 \%$ & $21.3 \%$ \\
\hline Mean & $11.2 \%$ & $43.0 \%$ & $25.9 \%$ & $19.8 \%$ \\
\hline \multicolumn{5}{|c|}{ Emerging Economies } \\
\hline China & $15.5 \%$ & $22.5 \%$ & $55.5 \%$ & $6.5 \%$ \\
\hline South Africa & $5.9 \%$ & $37.0 \%$ & $33.6 \%$ & $23.5 \%$ \\
\hline Brazil & $13.8 \%$ & $37.3 \%$ & $25.4 \%$ & $23.5 \%$ \\
\hline Mean & $14.2 \%$ & $29.9 \%$ & $40.8 \%$ & $15.1 \%$ \\
\hline
\end{tabular}

Source: Kerstenetzky and Machado (2018). 